\title{
Powdery Mildew Fungi from Phaltan Area of Satara District, Maharashtra
}

\author{
Prasad Bankar*, Vivek Kadam, Anuradha Bhosale, Sandhya Shitole, Sujit Wagh, \\ Sourabh Chandankar, Rupali Chitale and M.B. Kanade
}

\begin{abstract}
P. G. Research Center, Department of Botany, Tuljaram Chaturchand College of Arts, Science and Commerce, Baramati, Dist. Pune - 413 102, Maharashtra, India
\end{abstract}

*Corresponding author

A B S T R A C T

\section{Keywords}

Powdery mildew fungi, Host diversity

Article Info

Accepted:

17 June 2019

Available Online:

10 July 2019
Powdery mildew disease is becomes a serious and widespread problem in many parts of India and abroad. Powdery mildew fungi can grow superficially on leaves of host plants and at severity of infection causes morphological, anatomical and physiological damages of plants. In this connection present attempt has been made to study the diversity of powdery mildew from Phaltan area of Satara District of Maharashtra. Survey was carried during June, 2018 to April, 2019. During the study total 54 host plant species and 07 fungal genera of powdery mildew were reported.

\section{Introduction}

Powdery mildew fungi belong to order Erysiphales are most common obligate parasites (Takamatsu et al., 1998). These fungi produces enormous conidia on the host surface resulting in white powder coating and dusty appearance on the host surface hence they named as powdery mildew (Hasagoudar and Agrawal, 2009). The Erysiphaceae have dark and spherical perithecia, colourless, septate and uninucleate hyphae with upright conidiophores and conidia in chain. They are wide spread on about 7000 plant species including agricultural crops, vegetables, trees, herbs, shrubs, ornamentals and weeds (Thite and Kore, 2013; Gautam and Avasthi, 2018). They grow superficially on leaves and at severity of infection cause early leaf drop, chlorosis and stunted growth of host plant (Ajay Kumar, 2015). These fungi grow in abundantly in dry and cool seasons (Gautam and Avasthi, 2018). Depending upon the environmental conditions, this disease causes significant destructions and losses in crop plants and ultimately to the production (Pawar and Chavan, 2010).

Some powdery mildew diseases are externally destructive like Uncinula necator on grapes, Sphaerotheca pannosa on rose, S. fuligineara on cucurbits, Erysiphae graminis on cereals and grasses, E. polygoni on peas, Leveillula taurica on Medicago sativa, Phyllactinia dalbergiae on Dalbergia sissoo etc. In this connection, the present attempt was 
undertaken to investigate incidence of powdery mildew fungi and their host diversity from Phaltan area of Satara district, Maharashtra, India.

\section{Materials and Methods}

Survey was carried from different localities of Phaltan area during the period of June, 2018 to April, 2019. The collected samples were packed separately in sterilized polythene bags and noted with their locality, host name, date of collection, time and brought to laboratory for further analysis.

Powdery mildew fungi were identified by macroscopic and microscopic analysis of infected plant material. The leaf scraping was taken and slides were prepared by using cotton blue stain and lactophenol as mounting medium.

Slides were observed under light microscope and micro-photography was done. Powdery mildew fungal genera were identified on the basis of morphological characters of conidia and conidiophores and by using standard literature (Hasagoudar and Agrawal, 2009, Paul and Thakur, 2006).

\section{Results and Discussion}

The interesting results were noticed from present investigation. Total 54 plant species were noticed as the hosts of powdery mildew fungi. Present study reported tremendous diversity of host plants containing 09 vegetables (Abelmoschus esculentus, Anthus graveolens, Capsicum annuum, Coccinia grandis, Cucurbita maxima, Cyamopsis tetragonoloba, Daucus carota, Lagenaria vulgaris and Trigonella foenum-graecum), 03 fruit yielding plants (Mangifera indica, Punica granatum and Vitis vinifera), 03 floricultural plants (Rosa indica, Tagetes erecta and Zinnia elegans), 03 pulses (Phaseolous vulgaris,
Vigna radiata and Vigna unguiculata), 01 cereal (Triticum aestivum), 04 climbers (Clitoria ternatea, Cocculus hirsutus, Convolvulus arvensis and Tinospora cordifolia), 17 weeds (Acalypha indica, Achyranthes aspera, Balsam sp., Bellis perennis, Euphorbia geniculata, E. hirta, E. microphylla, E. tithymaloides, Indigofera trita, Lagascea mollis, Martynia annua, Mirabilis jalapa, Oxalis corniculata, Parthenium hysterophorus, Physalis minima, Sonchus oleraceus and Xanthium strumarium) and 14 wild plants (Abutilon indicum, Acacia arabica, Azadirachta indica, Brassica nigra, Cassia tora, Cordia dichotoma, Dalbergia sisso, Nyctanthes arbor-tristis, Ocimum sanctum, Phyllanthus niruri, Santalum album, Tamarindus indica, Tectona grandis and Ziziphus jujuba) (Table 1).

Total 07 fungal genera belonging to family Erysiphaceae and order Erysiphales were noticed as powdery mildew fungal genera. The reported fungal genera were Blumeria, Euoidium, Leveillula, Oidium, Ovulariopsis, Phyllactinia and Uncinula. The Oidium species was found as dominant species which was occurred on 46 host plant species followed by Ovulariopsis and Uncinula on 02 hosts, Blumeria, Euoidium, Leveillula and Phyllactinia on 01 host plant (Table 1). Gupta (1989) observed that atmospheric temperature was the most important factor for powdery mildew disease on set and epidemic development under field conditions and these fungi could cause disease from 15 to $32^{\circ} \mathrm{C}$ temperature and 15.5 to $100 \%$ relative humidity. In identification of powdery mildew fungi characters of fruiting body and their appendages plays very important role (Braun et al., 2006).

Powdery mildew of mango becomes a serious and widespread problem in many parts of India caused by Oidium mangiferae reported by Khandelwal et al., (2012). 
Table.1 List of the host plants of powdery mildew fungi from Phaltan area of Satara district of Maharashtra

\begin{tabular}{|c|c|c|c|}
\hline Sr. No. & Name of host plant & Host plant family & Powdery mildew fungus \\
\hline 1. & Abelmoschus esculentus & Malvaceae & Oidium sp. \\
\hline 2. & Abutilon indicum & Malvaceae & Oidium sp. \\
\hline 3. & Acacia arabica & Fabaceae & Oidium sp. \\
\hline 4. & Acalypha indica & Euphorbiaceae & Oidium acalyphae \\
\hline 5. & Achyranthes aspera & Amaranthaceae & Oidium sp. \\
\hline 6. & Anthus graveolens & Apiaceae & Oidium sp. \\
\hline 7. & Azadirachta indica & Meliaceae & Oidium azadirchtae \\
\hline 8. & Balsam sp. & Balsaminaceae & Oidiopsis taurica \\
\hline 9. & Bellis perennis & Asteraceae & Oidium sp. \\
\hline 10. & Brassica nigra & Brassicaceae & Oidium sp. \\
\hline 11. & Capsicum annuиm & Solanaceae & Oidium sp. \\
\hline 12. & Cassia tora & Fabaceae & Oidium cassiae \\
\hline 13. & Clitoria ternatea & Fabaceae & Oidium clitoriae \\
\hline 14. & Coccinia grandis & Cucurbitaceae & Oidium sp. \\
\hline 15. & Cocculus hirsutus & Menispermaceae & Oidium sp. \\
\hline 16. & Convolvulus arvensis & Convolvulaceae & Oidium sp. \\
\hline 17. & Cordia dichotoma & Boraginaceae & Ovulariopsis sp. \\
\hline 18. & Cucurbita maxima & Cucurbitaceae & Oidium sp. \\
\hline 19. & Cyamopsis tetragonoloba & Fabaceae & Leveillula taurica \\
\hline 20. & Dalbergia sisso & Fabaceae & Phyllactinia dalbergiae \\
\hline 21. & Daucus carota & Apiaceae & Oidium sp. \\
\hline 22. & Euphorbia geniculata & Euphorbiaceae & Oidium sp. \\
\hline 23. & Euphorbia hirta & Euphorbiaceae & Oidium sp. \\
\hline 24. & Euphorbia microphylla & Euphorbiaceae & Oidium sp. \\
\hline 25. & Euphorbia tithymaloides & Euphorbiaceae & Oidium sp. \\
\hline 26. & Indigofera trita & Fabaceae & Oidium sp. \\
\hline 27. & Lagascea mollis & Asteraceae & Oidium lagascae \\
\hline 28. & Lagenaria vulgaris & Cucurbitaceae & Oidium sp. \\
\hline 29. & Mangifera indica & Anacardiaceae & Oidium mangiferae \\
\hline 30. & Martynia аппиа & Martyniaceae & Oidium sp. \\
\hline 31. & Mirabilis jalapa & Nyctaginaceae & Oidium mirabilifolli \\
\hline 32. & Nyctanthes arbor-tristis & Oleaceae & Oidium braunii \\
\hline 33. & Ocimum sanctum & Lamiaceae & Euoidium labiatarum \\
\hline 34. & Oxalis corniculata & Oxalidaceae & Oidium sp. \\
\hline 35. & Parthenium hysterophorus & Asteraceae & Oidium parthenii \\
\hline 36. & Phaseolous vulgaris & Fabaceae & Oidium sp. \\
\hline 37. & Phyllanthus niruri & Phyllanthaceae & Oidium sp. \\
\hline 38. & Physalis minima & Solanaceae & Oidium sp. \\
\hline 39. & Punica granatum & Lythraceae & Oidium sp. \\
\hline 40. & Rosa indica & Rosaceae & Oidium rosacearum \\
\hline 41. & Santalum album & Santalaceae & Oidium santalacearum \\
\hline 42. & Sonchus oleraceus & Asteraceae & Oidium parthani \\
\hline 43. & Tagetes erecta & Asteraceae & Oidium sp. \\
\hline 44. & Tamarindus indica & Fabaceae & Oidium tamarindi \\
\hline 45. & Tectona grandis & Lamiaceae & Uncinula tectonae \\
\hline 46. & Tinospora cordifolia & Menispermaceae & Oidium sp. \\
\hline 47. & Trigonella foenum-graecum & Fabaceae & Oidium sp. \\
\hline 48. & Triticum aestivum & Poaceae & Blumeria graminis \\
\hline 49. & Vigna radiata & Fabaceae & Oidium sp. \\
\hline 50. & Vigna unguiculata & Fabaceae & Oidium sp. \\
\hline 51. & Vitis vinifera & Vitaceae & Uncinula necator \\
\hline 52. & Xanthium strumarium & Asteraceae & Oidium xanthami \\
\hline 53. & Zinnia elegans & Asteraceae & Oidium sp. \\
\hline 54. & Ziziphus jujuba & Rhamnaceae & Oidium zizyphi \\
\hline
\end{tabular}


Khan (1991) conducted his study to find out powdery mildew disease incidence and their severity from Uttar Pradesh and concluded that, Brassicaceae, Cucurbitaceae and Papilionaceae families were heavily suffer from infections. Surveys of powdery mildew fungi from Khandesh region of Maharashtra was carried out by Pawar and Patil (2011) during 2004 to 2005 and reported 35 wild plants species as hosts of powdery mildew fungi. Among this Oidium was major genus containing 19 species. Similar results were also recorded from present investigation.

Thite and Kore (2013) investigated the diversity of powdery mildew fungi from Satara district and reported 95 hosts belonging to 92 genera. Further they reported 92 anamorphic and 3 telomorphic stages of reported fungi and Oidium species was found as dominant. Shahare (2016) reported four different fungal species from Amravati, Maharashtra out of which Leveillula clavata was on Euphorbia geniculata host was firstly recorded. The checklist of powdery mildew fungi of Himachal Pradesh was published by Gautam and Avasthi (2018) and reported 15 genera and 92 species of powdery mildew fungi and 168 host plant species belonging to 122 genera and 49 families.

Pawar and Chavan (2010) studied the powdery mildew incidence on different cucurbits in different seasons and noticed that, in kharif season Sphaerotheca fuliginea was dominantly present on Cucurbita maxima, Lageneria siceraria and Cucurbita pepo and in the rabbi season Sphaerotheca fuliginea was dominantly found on Cucurbita maxima, Lageneria siceraria, Luffa acutangula and Luffa cylindrica. On the contrary we found Oidium as a dominant fungus on Cucurbitaceae members in our study. Also Pawar and Chavan (2010) reported the incidence of powdery mildew is more at post flowering and fruiting stages of host plants.
Biju et al., (2013) studied the diversity of powdery mildew fungi from Kerala and two newly recorded species were investigated i.e. Pseudoidium clitoriae on Clitoria ternate and Fibroidium balsaminae on Impatiens balsaminia. During the survey of powdery mildew fungi from Madhya Pradesh, Patel et al., (2015) first time recorded Pseudoidium santalacearum fungus on sandalwood from Mandsaur and Indore districts. We also found same fungus on same host from our study area.

Rodriguez-Alvarado et al., (2010) first time reported powdery mildew fungus Erysiphe heraclei on commercial carrot crop from Mexico. On the contrary they examined that, other Apiaceae members may not be infected, so it was concluding that Erysiphe heraclei is host specific.

According to Tuba et al., (2010) powdery mildew fungus Erysiphe polygoni is the one of the important biological constraint to the black gram [Vigna mungo (L.) Hepper]. Linde and Shishkoff (2003) noticed that, powdery mildew of roses is to be one of the major scourges of roses in Germany. Mariana Nakova (2012) studied the powdery mildew fungi of spinach caused by Uncinula sp. and Euoidium type anamorph from Bulgaria. They investigated that, infected plants have reduced growth, young leaves becomes small, matured leaves becomes yellowish and wilted in a short period.

Mwale et al., (2014) estimated damages of wheat infected by powdery mildew fungus Blumeria graminis (syn. Erysiphe graminis (DC) f.sp. tritici) and reported 13 to $30 \%$ damages in low to moderate infection and 50 to $100 \%$ damages when infection was severe. Gent et al., (2014) reported the economic loss of hop (Podosphaera macularis) due to infection of powdery mildew fungi from Washington State. 


\section{Acknowledgements}

Authors are sincerely thankful to Dr. Chandrashekhar Murumkar, Principal and Head, P. G. Research Center, Department of Botany, Tuljaram Chaturchand College of Arts, Science and Commerce, Baramati, Dist. Pune, MS, India for his constant guidance and encouragement.

\section{References}

Ajay Kumar Avasthi (2015). Studies on some powdery mildew of Himachal Pradesh, India. Australasian Mycologist, 32: 1013.

Biju, C.K., Thomas Sony, Sreekumar S., and Krishnan P.N. (2013). Additions to the powdery mildews of Kerala-II. Journal of Environmental Science, Toxicology and Food Technology, 6 (4): 31-33.

Braun Uwe, Takamatsu Susumu, Heluta Vasyl, Limkaisang Saranya, Divarangkoon Rangsi, Cook Roger and Boyle Herbert (2006). Phylogeny and taxonomy of powdery mildew fungi of Erysiphe sect. Uncinula on Carpinus species. Mycological Progress, 5: 139153.

Gautam, A. K. and Avasthi, S. (2018) Diversity of powdery mildew fungi from North Western Himalayan region of Himachal Pradesh - a checklist. Plant Pathology \& Quarantine, 8(1): 78-99.

Gautam, A.K. and Avasthi, S. (2018). Studies on some powdery mildew of Himachal Pradesh, India. Australasian Mycologist.

Gent, D. H., Grovec G. G., Nelsonb M. E., Wolfenbargerc S. N. and Woodsd J. L. (2014). Crop damage caused by powdery mildew on hop and its relationship to late season management. Plant Pathology, 63: 625-639.
Gupta, J. H. (1989). Perpetuation and epidemiology of powdery mildew of mango. Act Horticulture, Leuven, 231: 528-533.

Hasagoudar, V.B. and Agrawal D.K. (2009). Powdery mildew of India: check list. Associated Publishing Company, New Delhi, India.

Khan Ashraf Hambbd (1991). Studies on powdery mildews of some economically important plants. Dissertation submitted for the degree of Master of Philosophy in Botany. Department of Botany Aligarh Muslim University, Aligarh (India).

Khandelwal, V., Sharma H., Kalaria G. B. and Ghoghari P. D. (2012). Bioefficacy of different chemical fungicides for management of mango powdery mildew in South Gujarat. Journal of Mycology and Plant Pathology, 42 (4): 494-496.

Linde, M. and Shishkoff, N. (2003). Diseasepowdery mildew. Encyclopedia of Rose Science, 158-165.

Mariana Nakova (2012). Powdery mildew on Spinach (Spinacia oleraceae L.). Journal Pesticides and Phytomedicine (Belgrade), 27(2): 151-155.

Mwale, V.M., Chilembwe H.C., Uluko H.C. (2014). Wheat powdery mildew (Blumeria graminis f. sp. tritici): Damage effects and genetic resistance developed in wheat (Triticum aestivum). Journal of Plant Science, 5(1): 1-16.

Patel, R. P., Pandey, G. N., Gyanendra Tiwari, Patidar, H. and Patidar, D. K. (2015). First report of powdery mildew fungi on sandalwood in Madhya Pradesh. International Journal of Current Research, 7(6): 16705-16708.

Paul, Y.S and Thakur V.K. (2006). Indian Erysiphaceae. Scientific Publishers, Jodhpur (India).

Pawar, V. P. and Chavan A.M. (2010). Incidence of powdery mildew on cucurbit plants and its ecofriendly 
management. Journal of Ecobiotechnology, 2(6): 29-43.

Pawar, V.P. and Patil, V.A. (2011). Occurrence of powdery mildew on some wild plants from Khandesh region of Maharashtra state. Recent Research in Science and Technology, 3(5): 94-95.

Rodriguez-Alvarado, G., RodriguezFernandez, R., Soto-Plancarte, A., and Fernandez-Pavia, S.P. (2010). First report of powdery mildew on carrot caused by Erysiphe heraclei in Michoacan, Mexico. Article in Plant Disease, 94 (4): 483.

Shahare, N.H. (2016). Diversity of powdery mildew fungi on some local plants in Amravati, Maharashtra, India. Journal of Environmental Science, Toxicology and Food Technology, 10(2): 44-45.
Takamatsu Susumu, Hirata Tetsuya, Sato Yukio (1998). Phylogenetic analysis and predicted secondary structures of the rDNA internal transcribed spacers of the powdery mildew fungi (Erysiphaceae). Mycoscience, 39(4): 441-453.

Thite, S.V. and Kore B.A. (2013). Diversity of powdery mildew fungi from Satara District. International Journal of Multidisciplinary Research, II [7(V)]: 119-122.

Tuba Anjum, Sanjeev Gupta, K. and Subhojit Datta (2010). Mapping of mungbean Yellow Mosaic India Virus (MYMIV) and powdery mildew resistant gene in black gram [Vigna mungo (L.) Hepper]. Electronic Journal of Plant Breeding, 1(4): 1148-1152.

\section{How to cite this article:}

Prasad Bankar, Vivek Kadam, Anuradha Bhosale, Sandhya Shitole, Sujit Wagh, Sourabh Chandankar, Rupali Chitale and Kanade, M.B. 2019. Powdery Mildew Fungi from Phaltan Area of Satara District, Maharashtra. Int.J.Curr.Microbiol.App.Sci. 8(07): 2181-2186. doi: https://doi.org/10.20546/ijcmas.2019.807.264 